\title{
FAKTOR STRUKTURASI DALAM KOMODIFIKASI BERITA KRIMINAL BEGAL MOTOR DI DEPOK PADA MEDIA ONLINE
}

\author{
Berliana Lukitawati' ${ }^{1}$, Dr. Mulharnetti Syas ${ }^{2}$ \\ ${ }^{1,2}$ Program Magister Ilmu Komunikasi \\ Institut Ilmu Sosial dan Ilmu Politik Jakarta \\ Jl. Raya Lenteng Agung Jakarta Selatan, 12610 \\ Telp: (021) 7806223 Email: berlianajournal@ gmail.com
}

\begin{abstract}
Abstrak
Realitas pasar menggambarkan bahwa media berada dibawah tekanan ekonomi persaingan yang keras dan ketat, fungsi media sebagai pemberi edukasi dalam menyampaikan informasi yang benar telah bergeser. Berita-berita kriminal kembali menyedot perhatian pembacanya, dengan kehadiran kasus kriminal begal di Depok. Tampilannya vulgar baik secara foto, maupun teks. Baik di media cetak, elektronik, maupun siber. Hal ini tampak lebih nyata melalui penyajian gambar, foto, judul yang memblow up peristiwa kriminal, melalui faktor strukturasi yang membentuk komodifikasi berita. Mengingat kasus begal sesungguhnya hanyalah kasus lama yang berulang. Selain itu Depok yang justru memiliki jumlah data kejahatan begal terendah, namun memperoleh stigma sebagai kota Begal. Tujuan penelitian ini adalah untuk mengkaji realitas faktor strukturasi dalam komodifikasi berita begal motor di Depok yang direpresentasikan dalam media online. Obyek penelitian ini adalah Detik.com, Kompas.com, dan Liputan6.com. Bahan penelitiannya berita begal motor di Depok pada ketiga media tersebut. Unit analisisnya kata, kalimat, judul, lead, foto/gambar, grafis dan keseluruhan teks. Penelitian ini menggunakan metode analisis framing model Zhongdang Pan dan Gerald M. Kosicky.
\end{abstract}

Kata kunci: Strukturasi, Berita Krimminal, Media online

\begin{abstract}
The market reality illustrates that the media is under intense and tough economic competition. the function of the media as an educator in conveying the correct information has shifted. Crime news back to the attention of readers, with the presence of criminal cases in Depok. The appearance is vulgar both in photos, as well as text. Both in print, electronic, and cyber media.This is more evident through the presentation of pictures, photos, titles that blow up the criminal events, through the role of structuring that make up news commodification. Given a case of a begal is really just a recurring old case. In addition, Depok, which actually has the lowest amount data of Begal criminal, but gained stigma as a city of Begal. The purpose of this study is to examine the reality of the factor of structuring in the commodification of motorcycle news in Depok which is represented in online media.The object of this research is Detik.com, Kompas.com, and Liputan6.com. The material of research is Begal motorcycle of news in Depok on the three media. The unit analyzes words, sentences, titles, leads, and overall text. This research uses framing analysis method model of Zhongdang Pan and Gerald M. Kosicki.
\end{abstract}

Keywords: structure, crime news, online media. 


\section{Pendahuluan}

Pada beberapa tahun belakangan ini, beritaberita kriminal berhasil menyedot perhatian pembacanya, dengan kehadiran kasus kriminal begal. Tampilannyapun vulgar baik secara foto maupun teks. Baik di media cetak, media elektronik, maupun media siber. Dalam media online, hal ini tampak lebih nyata melalui penyajiannya yang terkesan vulgar, melalui penyajian gambar, foto, judul yang memblow up peristiwa kriminal

Tentu saja hal ini menjadi bermanfaat ketika masyarakat menjadi lebih waspada terutama mereka yang memiliki pemukiman di pinggiran dengan lokasi kerja yang cukup jauh. Mereka tentu harus berangkat pagi dan pulang petang. Kondisi inilah yang dimanfaatkan pelaku kriminal. Sehingga dengan pemberitaan ini masyarakat harus mencari jalan keluarnya.

Tingkat kesadaran dan kewaspadaan ini baik, namun disisi lain secara content berita tentu juga menimbulkan pertanyaan penulis akan adanya blow up, melalui proses strukturasi sebagai faktor yang membentuk komodifikasi.

Dengan adanya kebebasan media massa, berbagai media online mulai muncul dengan berbagai style eksposnya masing-masing. Tak hanya masalah ekonomi, tapi juga kriminal. Meskipun awalnya media memiliki kemurnian tujuan dalam memberikan edukasi melalui informasi yang benar, namun dalam perjalanannya, mengingat perkembangan ekonomi yang diiringi dengan persaingan bisnis dalam media massa, maka fungsi itupun kini mulai bergeser. Realitas pasar ini menggambarkan bahwa media berada dibawah tekanan ekonomi persaingan yang keras dan ketat (Haryatmoko, 2007:9).

Ironisnya, setelah melihat tingginya permintaan pasar, koran-koran yang semula termasuk koran berkualitas akhirnya mendirikan koran populer sebagai strategi diversifikasi produk. Selain itu, pada saat yang sama, tabloid berisi klenik dan supranatural lainnya terus bermunculan, disusul pula koran kriminal yang mengumbar peristiwa-peristiwa kekerasan dan kecelakaan dengan menampilkan foto-foto korban secara vulgar dan penuh darah.
Gambar mayat misalnya diekspos secara frontal di halaman muka dalam space berwarna yang cukup besar. Teknik penekanan gambar atau foto dengan zoom, close up, dan full colour secara terang-terangan mengeksploitasi tubuh mayat, layaknya gejala fethisisme. Dalam hal ini, koran telah memanfaatkan kematian sebagai komoditas (Yusuf: 2005: 91-92).

Berdasarkan hal tersebut terlihat bahwa media memiliki peran penting dalam pemberitaan melalui style eksposnya masingmasing. Dan tekanan ekonomi menjadi hal yang mendasari pemberitaan.

Hal ini menimbulkan pertanyaan penulis lebih lanjut akan adanya blow up, melalui proses strukturasi yang membentuk komodifikasi. Mengingat kasus begal sesungguhnya hanyalah kasus lama yang berulang. Disamping itu Depok yang justru memiliki jumlah data kejahatan begal terendah (http://news.okezone.com/read/2015/02/06/338 /1102111/nur-mahmudi-klaim kasus-begal-didepok-terendah), malah Depok mendapatkan stigma sebagai kota Begal.

Berdasarkan laporan CNN Indonesia.com, komisaris Jenderal Badrodin Haiti mengungkapkan bahwa kasus Begal di Indonesia, sudah berkurang dibanding tahun lalu yang berjumlah 932 kasus. Penyelesaiannya telah mengalami peningkatan sebesar $14 \%$, (http://www.cnnindonesia.com/nasional/20150 416155031-12-47179/badrodin-klaim-kasusbegal-berkurang).

Dalam laporan metro news.co.id menyeluruh dari 80 kasus di tahun 2014, Depok tergolong yang terendah, dibandingkan dengan wilayah lainnya seperti Bekasi yang tertinggi dalam Januari 2015, disusul Jakarta Timur, lalu Tangerang, kemudian Jakarta Selatan, (http://metro.news.viva.co.id/news/read/59457 1-januari-2015--ada-80-kasus-begal-motor)

Kecurigaan adanya blow up dan dramatisasi melalui proses strukturasi dalam penyajian berita begal, mendorong penulis untuk menelitinya. Dengan demikian dapat dikatakan bahwa penyajian berita ini telah mengalami 
bentuk komodifikasi melalui proses strukturasi, dari semula memiliki nilai guna dengan hanya memberikan informasi untuk kesadaran masyarakat menjadi berita yang memiliki nilai tukar, dengan tujuan ekonomi.

Dalam hal ini penulis mengambil media online sebagai media untuk penelitian. Adapun media online tersebut meliputi media Detik.com, Kompas.com dan Liputan 6.com. Dengan alasan ketiganya merupakan media online dengan rating tertinggi berdasarkan tingkat populernya di masyarakat menurut Alexa.

Menurut Moscow ( 2009:129), ada 3 konsep untuk aplikasi pendekatan ekonomi politik dalam industri komunikasi, yaitu Komodifikasi, spasialisasi, dan strukturasi. Komodifikasi dalam pengertian ini adalah segala sesuatu yang dikomoditaskan (dianggap barang dagangan). Spasialisasi adalah proses mengatasi hambatan jarak dan waktu dalam kehidupan sosial. Dan strukturasi merupakan penyeragaman ideologi secara terstruktur.

Penelitian ini fokus pada pembahasan mengenai faktor strukturasi dalam komodifikasi penyajian berita begal motor Depok di media online. Dimana segala sesuatu dapat dijadikan komoditas yang dapat memperkaya pemilik media. Khalayakpun semakin tidak sadar ketika mereka didikte mengenai penyajian begal dengan peran redaksi sebagai pelaku yang juga terkait dengan struktur media. Melalui faktor strukturasi dalam media ini terbentuklah komodifikasi.

Dengan demikian teori-teori yang digunakan dalam penelitian ini, yaitu terkait dengan teori ekonomi politik media, teori model analisis framing Zhongdang Pan dan Gerald $M$. Kosicki, teori komunikasi Shoemaker and Reese, teori konstruktivisme serta teori-teori komunikasi lainnya. Adapun teori-teori tersebut merupakan teori-teori yang berhubungan dengan penelitian.

Fairclough dengan analisis wacananya dalam Eriyanto terkait dengan teks, mengatakan bahwa teks berkaitan dengan bagaimana kejadian, situasi, hubungan dan orang yang direpresentasikan dalam teks. Ini berarti bahwa teks media bukan hanya sebagai cermin realitas tapi juga terdapat versi yang sesuai dengan posisi sosial, kepentingan dan sasaran yang memproduksi teks (Eriyanto, 2001:289-326). Sebagaimana yang diketahui, media membuat konten sedemikian rupa tidak hanya memberikan fungsi edukasi, informasi, atau persuasi saja, dibalik itu media juga membutuhkan dana yang tidak sedikit agar roda perekonomiannya tetap berjalan lancar. Pemberitaan di media online, khususnya Detik.com, Kompas.com, Liputan 6.com, menjadi latar belakang bagi penulis untuk melakukan penelitian tentang faktor strukturasi dalam komodifikasi berita kriminal begal motor di Depok.

\section{Metode}

Penelitian ini menggunakan metode analisis framing untuk menunjukkan bahwa isi media dipengaruhi oleh beberapa komponen yang terdapat dalam institusi media tersebut, dan dipengaruhi juga oleh sistem ekonomi media.

Eriyanto (2002, 10), mengatakan bahwa analisis framing adalah analisis yang dipakai utnuk melihat bagaimana media mengkonstruksi realitas.

Penelitian ini menggunakan metode analisis framing model Zhongdang Pan dan Gerald M. Kosicki. Zhongdang Pan dan Gerald M. Kosicki melihat framing sebagai cara untuk mengetahui bagaimana suatu media mengemas berita dan mengkonstruksi realitas melalui pemakaian strategis kata, kalimat, lead, hubungan antarkalimat, foto, grafik, dan perangkat lain untuk membantu dirinya mengungkapkan pemaknaan mereka sehingga dapat dipahami oleh pembaca

Model Pan dan Kosicky ini perangkatnya meliputi : sintaksis, skrip, tematik, dan retoris.

\section{1..Sintaksis}

Sintaksis berhubungan dengan bagaimana wartawan menyusun peristiwa, pernyataan, opini, kutipan, pengamatan atas peristiwa - ke dalam bentuk susunan kisah berita. Dengan demikian sintaksis dapat diamati dari bagian berita (headline yang dipilih, lead yang dipakai, latar informasi yang dijadikan sandaran, sumber yang dikutip dan sebagainya).

a.Headline (judul berita) 


\section{b. Lead (Teras berita)}

Lead yang baik pada umumnya memberikan sudut pandang dari berita.

c. Latar

Latar pada umumnya dimaksudkan untuk memberi kesan bahwa pendapat wartawan beralasan.

\section{d. Pengutipan sumber berita}

Bagian ini dimaksudkan untuk membangun obyektifitas, yaitu prinsip keseimbangan dan tidak memihak.( Eriyanto, 2002: 257-259)

\section{Skrip}

Skrip melihat bagaimana strategi bercerita.

\section{Tematik}

Dalam menulis berita, seorang wartawan mempunyai tema tertentu atas suatu peristiwa (Eriyanto, 2002: 255).

Ada beberapa elemen yang dapat diamati dari perangkat tematik ini, dintaranya adalah:Koherensi.

Koherensi adalah pertalian atau jalinan antar kata, proposisi atau kalimat. Sehingga fakta yang tidak berhubungan sekalipun dapat menjadi berhubungan ketika seseorang menghubungkannya.

Ada beberapa macam koherensi, yaitu sebagai berikut:

Koherensi sebab akibat

Pada koherensi ini proposisi atau kalimat satu dipandang akibat atau sebab dari proposisi lain.

Koherensi penjelas

Merupakan koherensi yang proposisi atau kalimat satu dilihat sebagai penjelas proposisi atau kalimat lain.

\section{Koherensi Pembeda}

Proposisi atau kalimat satu dipandang kebalikan atau lawan dari proposisi atau kalimat lain. Proposisi mana yang dipakai dalam teks berita, mudah dapat dilihat dari kata hubung yang dipakai ( Eriyanto, 2002: 263).

\section{Retoris}

Sedangkan retoris berhubungan dengan cara wartawan menekankan arti tertentu ke dalam kabar berita. Ada beberapa elemen retoris yang dipakai oleh wartawan diantaranya, yaitu:

\section{a. Leksikon}

Elemen leksikon pada dasarnya menandakan bagaimana seseorang melakukan pemilihan kata, atau frase yang tersedia. Pilihan kata-kata atau frase yang dipakai akan menunjukkan sikap dan ideologi tertentu (Sobur, 2002: 83)

\section{b. Grafis}

Misalnya pemakaian huruf tebal, huruf miring, pemakaian garis bawah, huruf yang dibuat dengan ukuran lebih besar, caption, raster, grafik, gambar, tabel, dan foto untuk mendukung arti penting dari suatu pesan. (Eriyanto, 2002:226).

Keempat elemen framing tersebut diatas merupakan suatu rangkaian yang dapat menunjukkan framing dari suatu media. ( Eriyanto, 2002: 255-264).

Tabel Elemen Model Zhongdang Pan \& Gerald M. Kosicki.

\begin{tabular}{|c|c|c|}
\hline $\begin{array}{l}\text { ELEMEN } \\
\text { FRAMIN } \\
\text { G }\end{array}$ & $\begin{array}{l}\text { PERANGKAT FRA } \\
\text { MING }\end{array}$ & $\begin{array}{l}\text { UNIT } \\
\text { YANG } \\
\text { DIAMATI }\end{array}$ \\
\hline $\begin{array}{l}\text { SINTAKS } \\
\text { SIS } \\
\text { Cara } \\
\text { wartawa } \\
\text { menyus } \\
\text { un kata }\end{array}$ & $\begin{array}{l}\text { 1. Skema } \\
\text { berita }\end{array}$ & $\begin{array}{l}\text { Headline, } \\
\text { lead, latar } \\
\text { informasi } \\
\text {,kutipan, } \\
\text { sumber, } \\
\text { pernyata } \\
\text { an, } \\
\text { penutup }\end{array}$ \\
\hline $\begin{array}{l}\text { SKRIP } \\
\text { Cara } \\
\text { wartawa } \\
\text { mengisa } \\
\text { kan } \\
\text { fakta }\end{array}$ & $\begin{array}{l}\text { 1. Kelengka } \\
\text { pa berita }\end{array}$ & $5 \mathrm{~W}+1 \mathrm{H}$ \\
\hline
\end{tabular}




\begin{tabular}{|c|c|c|}
\hline $\begin{array}{l}\text { TEMA } \\
\text { TIK } \\
\text { Cara } \\
\text { wartawa } \\
\text { menulis } \\
\text { fakta }\end{array}$ & 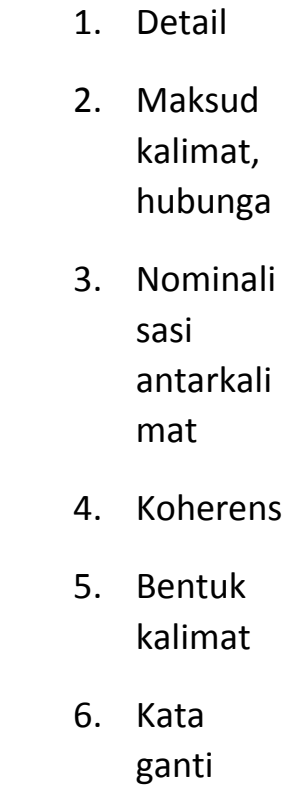 & $\begin{array}{l}\text { Paragraf, } \\
\text { proposisi }\end{array}$ \\
\hline $\begin{array}{l}\text { RETORIS } \\
\text { Cara } \\
\text { wartawa } \\
\text { meneka } \\
\text { nkan } \\
\text { fakta }\end{array}$ & $\begin{array}{l}\text { 1.Leksikon } \\
\text { 2.Grafis } \\
\text { 3.Metafor } \\
\text { 4.pengandaian }\end{array}$ & $\begin{array}{l}\text { Kata, } \\
\text { grafik, } \\
\text { idiom, } \\
\text { gambarfo } \\
\text { to. }\end{array}$ \\
\hline
\end{tabular}

Selain bahasa yang ikut mempengaruhi perbedaan penyajian berita dalam media, ada beberapa faktor lainnya yang juga ikut mempengaruhi penyajian berita seperti hubungan antara media dengan institusi sosial lainnya, rutnitas pekerjaan media, struktur dan budaya organisasi media, sikap pribadi, konsepsi peran para pekerja media, dan sebagainya. Hal ini sesuai dengan Shoemaker and Reese dalam Nasrullah (2014:41) yang mengatakan bahwa terdapat banyak faktor yang mempengaruhi isi media. Faktor itu terbagi atas dua bagian yaitu faktor didalam media (internal) dan faktor diluar media (eksternal).

Faktor didalam media berkaitan dengan karakteristik individu pekerja media dan rutinitas yang berlangsung dalam organisasi media. Sedangkan faktor diluar media adalah berkaitan dengan sumber-sumber informasi media, pengiklan, khalayak sasaran, kontrol pemerintah atau pasar media. Sedangkan ideologi terkait dengan sistem kepercayaan, nilai, dan makna yang digunakan oleh media massa untuk menentukan isi yang ditampilkan. Shoemaker dan Resse menyebut pengaruhpengaruh tersebut sebagai 'hierarchy of influence' yang merupakan lapisan-lapisan dalam institusi media.

Berikut ini adalah lingkaran 'hierarchy of influene' Shoemaker dan Resse.

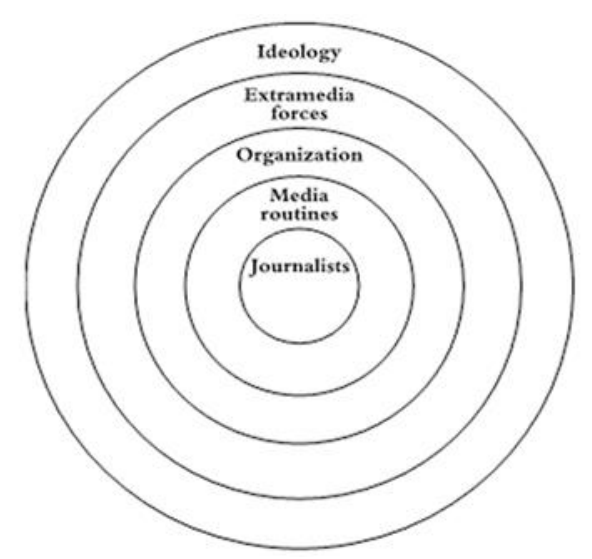

\section{Hasil Penelitian}

1.Pada Detik.com, terdapat komodifikasi berita begal motor di Depok. Komodifikasi tersebut terjadi pada judul, teks ataupun keseluruhan berita. Bahkan perubahan itu juga terjadi pada sisi angle berita.

Adapun Peran struktur dalam hal ini terkait dengan peran constraining (membatasi) dan peran enabling (memberdayakan). Dimana struktur dalam hal ini memberikan batasan (constraining) bagi redaksi sebagai pelaku/agen dalam bentuk aturan internal dalam redaksi. Aturan yang rutin dipatuhi tersebut terkait dengan pembatasan dalam pembentukan berita. Namun disisi lain struktur juga memberikan kemudahan/peluang (enabling) bagi pelaku/agen dalam redaksi untuk melakukan perubahan berita. Dalam hal ini berita mengalami blow up atau komodifikasi, setelah melalui pertimbangan pimpinan (editor dan pimpinan redaksi), demi meningkatkan perhatian pembaca atau page viewnya. Secara 
tidak langsung hal ini akan meningkatkan pemasukan iklan, dan menaikan income media sebagai sebuah industri. Maka berita yang dikirimkan oleh reporter diubah dengan cepat menjadi berita tayang yang fenomenal. Bahkan, perubahan itu juga dapat terjadi pada sisi angle berita, jika kondisi menuntut hal tersebut. Dengan harapan semakin tinggi jumlah pembaca, maka akan semakin tinggi harga iklan di media tersebut. Sehingga media sebagai industri ekonomi tentu akan lebih mampu bersaing di pasar. Maka struktur tidak hanya berperan dalam membatasi pelaku/agen melakukan perubahan dalam proses pembentukan berita, tapi juga berperan memberikan peluang atas komodifikasi tersebut.

2.Demikian pula halnya dengan Kompas.com, ketika terjadi perubahan berita yang dianggap mampu menaikkan page view pembacanya, maka struktur tak hanya berperan membatasi (constraining), tapi juga memudahkan (enabling). Struktur memberikan kemungkinan kepada pelaku dalam redaksi untuk melakukan tindakan, yakni agen mempunyai kekuasaan untuk melakukan pertentangan, meskipun struktur itu sendiri bersifat mengekang, namun struktur juga memberikan peluang bagi agen.

Dalam hal ini aturan internal redaksi yang ditaati oleh pimpinan redaksi dan editor, juga memberikan kemudahan hingga terbentuknya proses komodifikasi.

Dengan kata lain, terjadi perubahan berita di Kompas.com dalam bentuk blow up atau komodifikasi. Perubahan tersebut dapat terjadi pada judul, teks maupun keseluruhan berita, baik pada elemen framing sintaksis, skrip, tematik, maupun retoris. Hal ini tak lepas dari peran mereka sebagai industri yang tidak bisa mengharapkan dana funding. Maka mereka harus menyajikan berita dengan tingkat perhatian pembaca yang tinggi dengan tetap memperhatikan relevansinya.

3.Tak berbeda dengan keduanya, pada Liputan6.com hal inipun terjadi. Meskipun struktur dalam redaksi berperan sebagai constraining (membatasi) dalam proses pembentukan berita, tetapi ini tidak berarti bahwa pihak redaksi sebagai agen/pelaku tidak mempunyai pilihan dan tidak mempunyai peluang untuk membuat pertentangan. Pertentangan yang terjadi merupakan bentuk adanya orientasi dari adanya keinginan dari redaksi untuk mengubah situasi, yang melibatkan kekuasaan dan kemampuan.

Perubahan berita yang dibuat oleh editor melalui persetujuan pimpinan redaksi mengandung unsur komodifikasi karena memblow up berita. Meskipun hal ini bertentangan dari struktur dalam redaksi, atau aturan internal redaksi namun struktur dalam hal ini juga memiliki peran memberdayakan (enabling) dan memberikan peluang bagi pelaku redaksi untuk melakukan perubahan berita.

\section{Pembahasan}

Hasil penelitian ini menunjukkan dalam komodifikasi berita begal motor di Depok pada media online Detik.com, Kompas.com, Liputan6.com, dan struktur berperan sebagai constraining maupun enabling. Berdasarkan analisis teks, dapat terlihat bahwa dari seluruh sampel terkandung unsur komodifikasi, yaitu mengandung unsur yang memblow up berita atau gambar. Unsur tersebut tak lepas dari tujuan industri media dalam bergelut menghadapi persaingan berita dari industri media lain, yang tentu saja akan berujung pada kenaikan income industri media tersebut.

Komodifikasi telah terjadi dalam teks berita kriminal begal motor, dari yang semula memberikan nilai manfaat berupa peringatan akan bahaya kriminal begal menjadi sebuah ancaman. Dan selanjutnya akan banyak pembaca yang melihat media tersebut sebagai kompensasi dari minimnya pengetahuan. Pada akhirnya media diuntungkan dengan penyajian berita tersebut, karena berhasil meningkatkan page view mereka, yang akan berdampak secara tidak langsung pada pemasukan dari produsen iklan.

Terkait dengan terjadinya praktek komodifikasi ini sesungguhnya dapat terlihat bagaimana kapitalis melancarkan tujuannya yaitu dengan mengakumulasi kapital, atau menyadari transformasi nilai guna menjadi nilai tukar. Komoditas dan komodifikasi merupakan obyek dan proses yang menjadi salah satu indikator kapitalisme global yang kini tengah marak, dan tidak dapat dipungkiri keberadaannya.

Dalam ekonomi politik media, komodifikasi adalah salah satu bentuk penguasaan media selain strukturasi dan 
spasialisasi. Dalam hal ini industri media seperti Detik.com, Kompas.com dan Liputan6.com dapat dikatakan juga mengakumulasi kapital dengan cara menaikkan jumlah pembaca (page view) mereka, sehinga secara tidak langsung akan menaikkan harga iklan mereka.

Giddens sendiri tidak menyangkal bahwa struktur dapat memaksa dan mengendalikan individu. Ia beranggapan bahwa struktur mempunyai potensi untuk membatasi akan tetapi dilain pihak struktur juga memberikan kemungkinan pada agen untuk melakukan tindakan. Tindakan diartikan dalam hubungannya dengan struktur yang memaksa, yakni agen mempunyai kekuasaan untuk melakukan pertentangan. Meskipun struktur itu sendiri bersifat mengekang, namun struktur juga memberikan peluang bagi agen.

Dengan demikian tidak berarti bahwa agen tidak mempunyai pilihan dan tidak mempunyai peluang untuk membuat pertentangan. Pertentangan yang terjadi merupakan bentuk orientasi adanya keinginan untuk mengubah situasi, dimana dalam melakukan hal tersebut (pertentangan) merupakan sebuah tindakan, yang melibatkan kekuasaan dan kemampuan (Barker 2009:186).

Dengan demikian melalui pembahasan ini dapat penulis katakan bahwa editor dan pimpinan redaksi memiliki kekuasan atas struktur untuk melakukan perubahan berita, meski pembatasan dari struktur dalam hal ini aturan internal redaksi telah nyata. Peluang dari struktur (enabling) tentu memungkinkan bagi pelaku dalam redaksi mereproduksi kembali struktur yang telah ada menjadi struktur yang baru. Selain itu juga dapat penulis katakan bahwa dengan adanya peran enabling struktur yang memberdayakan dalam redaksi media, memungkinkan dikemudian hari struktur dalam redaksi mengalami reproduksi akibat interaksi antar agen/pelaku dalam redaksi maupun struktur itu sendiri.

Sebagaimana telah dijelaskan dalam kerangka teori bahwa terciptanya sebuah struktur dicipta-ulang di dalam dan dalam rangkaian praktik sosial yang berulang-ulang yang diorganisir oleh praktik sosial itu sendiri.

Struktur tercipta ketika seseorang melakukan praktik sosial secara berulang dan melintasi ruang dan waktu. Maksud ruang dan waktu disini yaitu dimana suatu kondisi tempat dimana individu berada dan bisa beradaptasi didalamnya (Barker 2005:185).

Dalam teorinya, praktik yang dilakukan oleh individu atau agen itu sendiri secara tidak langsung menciptakan struktur dan kesadaran. Artinya masalah ruang dan waktu merupakan proses historis yang mempengaruhi terbentuknya susunan yang terdapat dalam agen atau individu tersebut, yakni struktur (Gidden 2004:217).

Struktur diciptakan, dipertahankan, dan diubah melalui tindakan-tindakan agen/pelaku. Sedangkan tindakan-tindakan itu sendiri diberi bentuk yang bermakna (meaningful form) hanya melalui kerangka struktur. Hal ini berlangsung ke dua arah secara timbal-balik, sehingga tidak memungkinkan bagi kita untuk menentukan apa yang mengubah apa. (Gidden 1979:204).

Dengan demikian dapat penulis katakan melalui pembahasan ini bahwa struktur yang terbentuk dalam redaksi media tentu juga diciptakan, dipertahankan dan diubah melalui tindakan-tindakan pelaku dalam redaksi. Dan tentunya melalui proses pengulangan tindakan.

Terkait dengan komodifikasi melalui faktor strukturasi karena tekanan ekonomi industri juga tampak jelas dalam wawancara dengan Editor di Kompas.com.

kita harus akui bahwa semua media sebagai industry harus memperhatikan hal itu. Dengan fokus pada pemberitaan yang menjadi perhatian kerumunan maka trafficnya juga tinggi. Nah inilah nanti yang akan dikapitalisasi menjadi iklan. Dari traffic atau pageview tersebut kan akan ketahuan berapa orang yang kunjugi. Ini yang bisa kita pakai buat jualan iklan. TV menggunakan sistem rating, radio memakai sistem pendengar, dan media cetak memakai oplaag untuk dikapitalissasi sebagai jualan iklan. Nah online itu dari traffic atau pageview. Mereka tidak mungkin mengharapkan dana funding, dengan demikian pasti dalam berita ada harga yang kita juga mengakuinya.

Selain itu dikatakannya juga terkait akurasi berita.

Berita itu kan harus bersaing dengan cepat dan tepat. Supaya bisa punya traffic 
atau page view yang cukup banyak untuk jualan kita di iklan. Ini kan ada problemproblem seperti sumber berita, dan lainnya untuk mengejar kecepatan ... karakter online itu beda, tidak seperti media cetak jadi berita, harus diberitakan hari ini juga. Jika bicara akurasi.....malah majalah dan lainnya juga mengalami masalah akurasi. Tapi audience mengakui bahwa soal akurasi itu sebenarnya problem semиa media.

( wawancara 26 Januari 2016).

Dengan demikian dapat diketahui bahwa masalah akurasi menjadi kepentingan kedua setelah kecepatan berita, dengan tetap mendasari pada page view mereka.

Demikian pula dalam wawancara dengan Editor Detik.com terkait dengan komodifikasi melalui faktor strukturasi karena tekanan ekonomi industri.

Berita kekerasan itu kan ada sadisnya banyak yang baca, nah untuk mempercantik perlu diubah supaya tidak datar tapi yang penting substansi tidak diubah, lebih ke kosakata aja yang diubah supaya bombastis. Nah istilah begal ini punya nilai sadisnya, sehingga ketika kita lihat, sepertinya boleh juga ini....buat eye catching kosakatanya. Jadi terkadang juga kita ubah, kita akan lihat anglenya apakah perlu diubah setelah dibuat oleh reporter. Kadang supaya tidak bosan oleh pembaca, maka kita ubah. Mungkin angle kita tampilkan dari korbannya, atau pelakunya dan sebagainya.

\section{Lebih lanjut dikatakan bahwa}

Yang pasti standar kita ada fakta yang tidak berbohong, jadi harus ada cross cek, misal korban ternyata masih hidup, maka kita harus lihat lagi nih info dari mana salahnya..apakah polisi atau saksi. Tapi yang penting berita sudah naik dulu, yang penting kita sudah menang tendangan dulu... karena kadang kita memperoleh berita dari nara sumber ya seperti adanya saat itu, misal dari polisi dikatakan meninggal, tapi yang penting tidak mengarang.
Selain itu terkait dengan komodifikasi melalui faktor strukturasi dalam wawancara dengan editor liputan 6.com, bahwa perubahan berita mengikuti trend pembaca dikatakan:

Kalau isu itu sedang menjadi perbincangan di masyarakat dan netizen, pasti informasi itu punya nilai berita tinggi. Praktis akan mendulang traffic yang bagus. Dan trafic memang menjadi faktor pertimbangan dalam memproduksi berita. Memang ada proses itu, berita harus dibuat menarik berdasarkan fakta yang ditemukan. Bila perlu cari angle yang berbeda. Dari situ diharapkan trafik tinggi. (wawancara 22 Januari 2016)

\section{Kesimpulan}

Berdasarkan hasil penelitian telah ditemukan adanya komodifikasi pemberitaan begal motor di Depok pada Detik.com, Kompas.com dan Liputan 6.com. Dalam hal ini struktur berperan secara constraining( membatasi) maupun enabling(memberdayakan).

Di Detik.com peran struktur dalam proses pembentukan berita hingga terjadinya komodifikasi, merupakan bukti bahwa struktur dalam bentuk aturan internal redaksi yang dipatuhi oleh pelaku/agen tak hanya menjalankan perannya sebagai constraining yang membatasi, tapi juga memberikan peluang bagi pelaku dalam redaksi untuk melakukan perubahan berita (enabling). Perubahan inilah yang pada akhirnya menghasilkan komodifikasi konten yang tentu dengan tujuan memperoleh income dari produsen iklan. Komodifikasi tersebut terjadi dalam elemen framing sintaksis, skrip, retoris dan tematik.

Melalui teks berita yang dibuat Detik.com, pembaca digiring untuk memahami realitas yang telah dibingkai oleh media tersebut. Pemahamannya terhadap realitas tergantung pada realitas yang dibentuk media. Pembaca telah terperangkap oleh pola konstruksi media tersebut. Selain menginformasikan sesuatu, Detik.com juga memaknakan sesuatu lewat berita-berita yang disuguhkan kepada pembaca.

Detik.com memiliki pola yang terbentuk melalui aktivitas yang dicipta ulang oleh pelaku atau dengan kata lain melalui produksi dan reproduksi aktivitas, yang menjadi struktur 
sosial. Pelaku/agen dalam redaksi ini memiliki peran dalam pembentukan pesan bagi Detik.com. Termasuk terjadinya pesan-pesan yang memblow up berita sehingga terbentuklah komodifikasi konten dalam pemberitaannya. Sedangkan struktur dalam redaksi dalam bentuk aturan internal yang dipatuhi pelaku/agen berperan yang membatasi sekaligus juga memberdayakan bagi proses tersebut.

Di Kompas.com hal serupa juga terjadi. Berita yang seharusnya dikendalikan oleh reporter, menjadi dominan dikendalikan oleh pimpinan, dengan tujuan ekonomi. Proses Komodifikasi terjadi pada elemen framing sintaksis, skrip, tematik dan retoris. Hal ini terlihat dalam analisis teks dan wawancaranya. Dengan demikian struktur dalam media atau aturan internal yang dipatuhi oleh pelaku/agen redaksi tak hanya berperan dalam memberikan batasan bagi pembentukan berita, namun dalam proses komodifikasi tersebut, struktur juga memberikan peluang bagi pelaku redaksi/agen untuk melakukan perubahan berita. Dan tak terlepas kemungkinan dengan adanya pengulangan aktivitas ini akan mereproduksi struktur tersebut.

Di Liputan 6.com strukturpun menjalankan kedua peran tersebut yaitu constraining (membatasi) dan enabling (memberdayakan), sebagaimana media online Detik.com dan Kompas.com. Perubahan berita dalam bentuk komodifikasi dapat terlihat pada elemen framing sintaksis, skrip, tematik maupun retoris. Baik judul, teks maupun gambarnya. Dan dalam proses yang berulang antara pelaku dalam redaksi dan struktur tentu tak menutup kemungkinan struktur tersebut akan mereproduksi sebagai sebuah hasil (outcome). Aturan internal redaksi yang dipatuhi oleh pelaku/agen. Dalam hal pembatasan juga mampu memberikan peluang bagi perubahan berita, sehingga terjadi proses komodifikasi tersebut. Komodifikasi terjadi dalam elemen framing sintaksis, skrip, retoris maupun tematik.

\section{Saran}

Hasil penelitian ini menunjukkan bahwa studi ekonomi politik media massa khususnya peran struktur dalam komodifikasi pada media online harus dikaji secara menyeluruh, tidak hanya dari konsep itu saja. Namun juga bisa diberikan kajian secara konsep spasialisasinya dan strukturasinya, agar dapat diberikan gambaran secara menyeluruh mengenai ekonomi politik media yang terkait dengan obyek penelitian. Selain itu juga perlu membandingkan data penelitian atas peningkatan page view dengan adanya komodifikasi dalam media tersebut.

Untuk penelitian selanjutnya disarankan menggunakan seluruh konsep dan teori ekonomi politik media, yaitu komodifikasi, strukturasi dan spasialisasi.

\section{DAFTAR PUSTAKA \\ A Buku}

Eriyanto. Analisis Framing, Konstruksi Ideologi dan Politik Media, Jogjakarta: LKIS; 2002

Vincent Mosco. The Political Economy of Communication, USA: The University of Wisconsin Press; 2009 Sugiyono. Metode Penelitian Kuantitatif,
Kualitatif, Bandung: Alfabeta; 2009

Haryatmoko. Etika komunikasi, Manipulasi media, kekerasan dan pornografi, Yogyakarta: Kanisius; 2007

Shoemaker\& Resse. Mediating the message Theories of influences on massmedia content, USA: Longman Publications Media; 1996

B. Tesis

Bernadette. Komodifikasi Tayangan Kriminalitas TKP TV 7;2005

Herlinawaty. Komodifikai sosok perempuan yang menjadi korban Kriminalitas;2014

Rachmaria. Komodifikasi Pemberitaan Terorisme di Global TV;2012

\section{Jurnal}

Hidayat Deddy Nur. Jurnal Penelitian Ilmiiah Komunikasi, Thesis Volume III/no 3: Departemen Ilmu Komunikasi dan Ilmu Politik Universitas Indonesia;2004 
D. Internet

Effendy. Pengertian Surat Kabar. Dapat

diakses di

https://tulisandila.wordpress.com/2013/02/

16/pengertian-surat-kabar;2013

Patton. Analisis Data Penelitian. Dapat

diakses di http://www.informasi-

pendidikan.com/2013/08/analisis-data-

penelitian.html; 2013

Badrodin. Kasus Begal berkurang. Dapat

diakses di

http://www.cnnindonesia.com/nasional/20

150416155031-12-47179/badrodin-klaim-

kasus-begal-berkurang;2015

Nur Mahmudi. Klaim kasus begal di

Depok terendah. Dapat di akses di

http://news.okezone.com/read/2015/02/06/

338/1102111/nur-mahmudi-klaim-kasus-

begal-di-depok-terendah; 2015

Yusuf, Awaludin. Menelisik Sejarah

Koran kuning di Indonesia. Dapat diakses

di

https://bincangmedia.wordpress.com/2010/

04/30 Sejarah Koran kuning; 2010 